\title{
On the Role of Linguistics in Ecosystem Management
}

\author{
Nwankwo Kalu Nnabueze ${ }^{1 *}$, and Yulia Zakirova ${ }^{2}$ \\ ${ }^{1}$ Abia State University, Uturu, Nigeria \\ ${ }^{2}$ Peoples' Friendship University of Russia (RUDN University), 115093 Podolskoe Schosse 8/5, \\ Moscow, Russian Federation
}

\begin{abstract}
Ecosystem management is a speciality guaranteeing quality in knowledge towards management and modernization of innovations in ecology. Effective ecosystem management demands tools to overcome the difficulties and limitations of methodologies in the development and implementation of environmental policies. To achieve the appropriate application of principles of knowledge in different languages, the relevance of Linguistics emerges. The main purpose of this study is to develop an understanding of the fact that making use of resources from Linguistics is specific in the direction of understanding the mechanics of language. which creates a platform for a better understanding of the maintenance of natural resource in various languages. Ecosystem management is essential to the harmony of the natural habitats of organisms. Management of natural resources and habitats are necessary regardless of uncertainty. Ignoring tradeoffs among ecosystem services can create unwanted management outcomes.
\end{abstract}

\section{Introduction}

Changes in the environment are mostly caused by anthropogenic load, which has a great influence on the ecosystems. The ecosystem response to such changes can be complex and unpredictable. Ecosystem management must deal with great uncertainty and surprise. An ecological research priority is therefore to develop a management scheme that can secure essential ecosystem functions and services in highly stochastic environments. Contending climate change will involve using all existing tools and options such as natural resource protection and energy security. Ecological science, researchers and scientists have established that $30 \%$ of global anthropogenic carbon dioxide emissions are absorbed through carbon sequestration from plant growth and associated ecological processes [6]. Degradation of ecosystems has very strong consequences which affect the health of humans, plant and animals. This has also led to the rapid mutation of harmful microorganisms. Ecosystem management can go a long way to reduce or thwart harmful emissions, land, soil, water and air degradation.

\footnotetext{
* Corresponding author: esteemedthelson@yahoo.com
} 


\section{Limitations and function of ecosystem management and protection}

Ecosystems provide a full array of goods and services upon which people depend for their livelihood and well-being [4]. Human destruction of the ecosystem takes place regularly, e.g. there are mega constructions such as the building of dams, clearing of forests which are a natural habitat to millions of animals to build new cities, skyscrapers and parks. The existence of life on earth depends solely on the harmony and balance in the ecosystem.

Table 1. Functions and benefits of ecosystems [4].

\begin{tabular}{|c|c|c|}
\hline Biome & $\begin{array}{l}\text { Functions and services } \\
\text { provided by ecosystems }\end{array}$ & $\begin{array}{l}\text { Common ecosystem } \\
\text { benefits and attributes }\end{array}$ \\
\hline Mangroves & $\begin{array}{l}\text { Storm protection, } \\
\text { Provision and renewal of } \\
\text { nutrients, } \\
\text { accumulation. }\end{array}$ & $\begin{array}{l}\text { Aesthetic and recreational } \\
\text { values, historical and } \\
\text { cultural values, fish } \\
\text { nurseries and fisheries } \\
\text { products. }\end{array}$ \\
\hline Forests & $\begin{array}{l}\text { Micro-climate stabilization, } \\
\text { Carbon uptake and storage, } \\
\text { Soil and watershed } \\
\text { protection, Energy storage }\end{array}$ & $\begin{array}{l}\text { Carbon dioxide removal, } \\
\text { non-timber products, } \\
\text { wildlife resources, timber } \\
\text { products, fuel products } \\
\text { biodiversity conservation }\end{array}$ \\
\hline Oceans & Global climate regulation & Fisheries products \\
\hline Wetlands & $\begin{array}{l}\text { Groundwater recharge and } \\
\text { discharge, flood control, } \\
\text { water quality and quantity, } \\
\text { water purification, } \\
\text { sediment/toxicant/nutrient } \\
\text { retention }\end{array}$ & $\begin{array}{l}\text { medicinal and biomedical } \\
\text { products, water supply, } \\
\text { pollution clean-up, fish } \\
\text { nurseries and fisheries } \\
\text { products, forage products, } \\
\text { agricultural products, } \\
\text { transport }\end{array}$ \\
\hline Coral Reefs & $\begin{array}{l}\text { Coastal protection, sand } \\
\text { production }\end{array}$ & $\begin{array}{l}\text { construction material, } \\
\text { genetic resources, global } \\
\text { heritage, educational and } \\
\text { scientific interest }\end{array}$ \\
\hline
\end{tabular}

Limitations of ecosystem management and protection are as a result of inadequate information for the development of models to get reliable predictions of real scenario and assets of ecosystems. The choice of the suitable ecological model is influenced by the nature of the problem to be solved and on the nature of the existing dataset. The assessment standards can be scientific or economical.

\section{Impact of climate change}

Temperature changes alter the great patterns of rainfall that bring flooding and erosion in West Africa, making drought and unpredictable weather more common in other regions of the world. A change in climate leads to the vulnerability of the environment and natural resources. Climate change assessments combine different studies from multiple disciplines and scientific research to understand and categorize the presumed effects of change in the 
climate. The assessments can focus on understanding properly system's sensitivity to climate change, predict climate changes and what is causing them, possible consequences of climate change.

In the Southern and central regions of Europe there have been more frequent heat waves, forest fires and droughts. In the Mediterranean areas precipitation level area dropping, putting it at risk to drought and wildfires. Northern parts of the European states are significantly wetter with winter floods. Urban areas, where 10 out of 15 Europeans now live, are put in danger to heatwaves, flooding or rising sea levels, but are often ill-equipped for adapting to climate change [3].

Damage to natural habitats, properties, infrastructures and human health imposes severe expenses on society and the economy. Between 1975 and 2018 floods affected more than 10 million people and caused direct economic losses of more than $\$ 120$ billion.

In Rwanda, over 55 people have died and floods have killed over 16 in Somalia. In Uganda, high water levels have trapped patients in a hospital. The water has also washed away over 8,000 acres of crops and some very important infrastructure. In western Uganda, a river burst its banks. People fled for shelter to the town of Kasese. At the end of each year, rain triggers disasters, including flash floods and landslides, which kill about 50 people and affects thousands of people across East Africa.

Coastal erosion has destructive and overwhelming effects, inducing the loss of infrastructure such as roads, water pipeline and electrical structures. In the Northwest of Africa, the coasts are economically important since a large part of the gross domestic product (GDP) is derived from coastal activities such as fishing, tourism and commerce [7]. In the Northwest coast of Africa, average rates of the coastal retreat are between one and two meters per year. It also threatens populations, who can no longer live close to the coastline. It is expected to rise as a result of climate change and sea-level rise. This will bring other problems such as salinisation of water and soils, degradation of ecosystems, habitats and flooding. Such predictions were reiterated in the fourth Intergovernmental Panel on Climate Change (IPCC) report [7]. South Asian countries lose billions of dollars as a result of soil erosion and other forms of land degradation. The total cost of replenishing soil nutrients and the cost of land reclamation and restoration are very expensive.

Earthquakes with epicentres off the Northern Sumatra and resultant tsunamis had hit Southeast Asia and caused serious damage and loss of life and properties. The first, strongest quake was on 26 December 2004. The quake had a magnitude of 8.9 on the Richter Scale, followed by a second severe quake. Indonesia, Sri Lanka, Maldives, India and Thailand have been affected as well as Malaysia, Bangladesh and Myanmar.

Specifically, weather and climate-related losses amounted to EUR 453 billion (at 2017 Euro values (3)), at an average of EUR 12 billion per year, EUR 79200 per square kilometre or EUR 811 per capita [4)]. The cumulative deflated losses over the period analysed are equal to nearly $3 \%$ of the GDP of all EEA member countries in 2017. Overall, around $35 \%$ of the Romania and Lithuania to $70 \%$ in the UK [2] 
Table 2. Impacts of extreme weather and climate-related events in the EEA member countries (1980-2017) [2].

\begin{tabular}{|l|l|l|l|l|l|l|}
\hline Country & $\begin{array}{l}\text { Losses } \\
\text { (million } \\
\text { Euro) }\end{array}$ & $\begin{array}{l}\text { Loss per } \\
\text { capita } \\
\text { (Euro) }\end{array}$ & $\begin{array}{l}\text { Loss per } \\
\text { sq.km } \\
\text { (Euro) }\end{array}$ & $\begin{array}{l}\text { Insured } \\
\text { losses } \\
\text { (million } \\
\text { Euro) }\end{array}$ & $\begin{array}{l}\text { Insured } \\
\text { losses } \\
(\%)\end{array}$ & Fatalities \\
\hline Austria & 13,489 & 1,681 & 160,818 & 4,156 & 31 & 595 \\
\hline Belgium & 4,308 & 415 & 141,125 & 2,531 & 59 & 2,168 \\
\hline Bulgaria & 2,452 & 302 & 22,217 & 129 & 5 & 205 \\
\hline Croatia & 3,014 & 674 & 53,256 & 74 & 2 & 722 \\
\hline Denmark & 10,336 & 1,936 & 240,838 & 6,307 & 61 & 42 \\
\hline Finland & 1,959 & 380 & 5,789 & 397 & 20 & 4 \\
\hline France & 62,059 & 1,026 & 98,011 & 30,961 & 50 & 23,415 \\
\hline Germany & 96,494 & 1,271 & 270,008 & 45,188 & 47 & 9,856 \\
\hline Greece & 7,319 & 693 & 55,424 & 113 & 2 & 2,431 \\
\hline Hungary & 6,035 & 588 & 64,881 & 137 & 2 & 703 \\
\hline Iceland & 88 & 312 & 850 & 43 & 50 & 52 \\
\hline Ireland & 4,014 & 1,017 & 57,515 & 2,059 & 51 & 69 \\
\hline Italy & 64,673 & 1,120 & 214,099 & 2,918 & 5 & 20,657 \\
\hline Latvia & 412 & 175 & 6,380 & 49 & 12 & 103 \\
\hline Luxembourg & 718 & 1,627 & 277,817 & 424 & 59 & 130 \\
\hline Netherlands & 8,111 & 517 & 195,240 & 3,771 & 46 & 1,729 \\
\hline Norway & 3,597 & 794 & 11,110 & 1,977 & 55 & 40 \\
\hline Poland & 15,057 & 397 & 48,155 & 1,027 & 7 & 1,217 \\
\hline Portugal & 6,869 & 672 & 74,475 & 584 & 9 & 3,108 \\
\hline Spain & 37,106 & 889 & 73,341 & 4,508 & 12 & 14,611 \\
\hline Sweden & 4,272 & 479 & 9,741 & 1,165 & 27 & 46 \\
\hline Switzerland & 18,805 & 2,609 & 455,431 & 9,621 & 51 & 1,160 \\
\hline $\begin{array}{l}\text { United } \\
\text { Kingdom }\end{array}$ & 50,504 & 848 & 203,208 & 35,106 & 70 & 3,535 \\
\hline
\end{tabular}

The increasing exposure of people and economic assets to weather and climate-related disasters has been the major cause of long-term increases in economic losses from them. Available studies for economic losses from river floods and storms in Europe suggest that the observed increases in losses are primarily because of increases in populations, economic wealth and developments in hazard-prone areas, but the observed increase in heavy precipitation in parts of Europe may have also played a role. 
Table 3. Earthquake Magnitude Japan [5].

\begin{tabular}{|l|l|l|l|}
\hline Date & Magnitude & Death troll & Name of quake \\
\hline March 11,2011 & $9.1 \mathrm{Mw}$ & Over 20,000 & $\begin{array}{l}2011 \\
\text { earthquake }\end{array}$ \\
\hline January 1,2012 & $6.8 \mathrm{Mw}$ & 0 & Izu Islands, Japan \\
\hline April 14, 2016 & $7.0 \mathrm{Mw}$ & 49 & $\begin{array}{l}\text { Kumamoto } \\
\text { earthquakes }\end{array}$ \\
\hline November 22,2016 & $7.4 \mathrm{Mw}$ & 0 & $\begin{array}{l}\text { Fukushima } \\
\text { earthquake }\end{array}$ \\
\hline June 18,2018 & $6.1 \mathrm{Mw}$ & 3 & \begin{tabular}{l} 
Osaka earthquake \\
\hline September 6,2018
\end{tabular} \\
\hline June 18,2019 & $6.7 \mathrm{Mw}$ & 41 & $\begin{array}{l}\text { Hokkaido Eastern } \\
\text { Iburi earthquake }\end{array}$ \\
\hline
\end{tabular}

\section{The role of Linguistics in ecosystem management}

Ecolinguistics is committed to ecological and dialectical epistemologies, which has significant theoretical and practical implications for human's collective responses to the worsening situation of global ecological crises [1]. Linguistic knowledge helps environmentalists and researchers to better explain ecological approaches in a different language. Linguistics helps linguists and ecologists to convey words, concepts and research discoveries, in modern-day relevance. Environmental linguistics helps students have an indepth understanding of their coursework and work product expectations.

Linguistics studies environmental terms (eco-terms), mechanisms of their appearance in a language (borrowing, metaphorization, etc.), their lexico-grammatical and functionalsemantic features.

Eco-terms provide the nomination of the basic interconnected concepts of environmental field of knowledge. The examples of environmental terms are the following: acid rain, aquaculture, climate change, deforestation, desertification, landfill, municipal waste, rain garden, renewable energy, etc.

Eco-terms are an integral fragment of the picture of the world since they function the same type in comparable languages, naming scientific concepts, processes, phenomena and objects. Eco-terms belonging to different thematic groups form open hierarchical language subsystems - functional-semantic field with a nuclear and peripheral zones.

When studying environmental terms in Linguistics along with general scientific methods such as observation, description, induction, deduction the following methods of research are used: the comparative method, the contrastive method, the lexical-grammatical analysis, the functional-semantic analysis, contextual analysis, etc.

Linguistic knowledge in the field of ecology has great potential for contributing to trans-disciplinary collaborations among environmental research fields such as environmental studies, ecology, and environmental communication [1]. Applied Linguistics helps ecologists to have a better learning experience and more high-level and complex view of language, knowledge acquisition, and knowledge use which takes into account the insights from environmental research. To better understand how to solve ecosystem degradation problem and manage the ecosystem, researchers, scientists, ecologists and environmentalists including politicians have to put heads together to agree on policies and approaches to protect natural resources and habitats. In most cases, there is a language 
barrier when dealing with such scenarios, Linguistics plays a crucial role to help deal with them.

\section{Conclusion}

Ecosystem management is vital to ensure that life is sustained on our planet. Deteriorating human health, climate change, environmental degradation, and increasing human population requires a sustainable ecosystem to thrive on. Soil and water degradation weakens food production and the availability of clean potable water, thereby threatening human health and economic performance of society at large.

To a large extent global environmental negotiations and management are political. During such important negotiations, Ecolinguistics with its unique insights on the interactions between language and ecology makes important contributions. linguistics is crucial in understanding different language ideologies and can strengthen the representation of a less common, minority language or maintain a representation of a dominant language. Linguistics studies environmental terms (eco-terms), mechanisms of their appearance in a language (borrowing, metaphorization, etc.), their lexico-grammatical and functionalsemantic features.

Eco-terms provide the nomination of the basic interconnected concepts of environmental field of knowledge.

Eco-terms are an integral fragment of the picture of the world since they function the same type in comparable languages, naming scientific concepts, processes, phenomena and objects. Eco-terms belonging to different thematic groups form open hierarchical language subsystems - functional-semantic field with a nuclear and peripheral zones.

\section{Acknowledgements}

This work was supported by the Russian Foundation for Basic Research, grant No.17-3410303

This paper was financially supported by the Russian Foundation for Basic Research, grant No. 20-012-22046.

\section{References}

1. S. Chen, Language and ecology: a content analysis of ecolinguistics, https://core.ac.uk/download/pdf/82541487.pdf, (2016)

2. EEA Economic losses from climate-related extremes in Europe. Retrieved from European Environment Agency: https://www.eea.europa.eu/data-andmaps/indicators/direct-losses-from-weather-disasters-3/assessment-2 (2019, April)

3. EC. Climate change consequences. Retrieved from European Commission: https://ec.europa.eu/clima/change/consequences_en (2020)

4. Jean-Yves pilot, p. j. M. Ecosystem management: lessons from around the world, https://www.cbd.int/doc/meetings/esa/ecosys-01/information/ecosys-01-inf-08-en.pdf, (2000)

5. JMA.Earthquake Information. Retrieved from Japan Meteorological Agency: https://www.jma.go.jp/en/quake

6. Le quéré c, et al. Global carbon budget 2015, Earth Syst sci data 7:349 -396. Cross ref googles scholar (2015) 
7. I. Niang, Coastal erosion major threat to West Africa. Retrieved from Climate Home News: https://www.climatechangenews.com/2012/01/26/coastal-erosionmajor-threat-to-west-africa (2012)

8. USDA. Climate Change Assessments. United States Department of Agriculture: https://www.fs.usda.gov/sites/default/files/ccassessments.pdf (2018, May) 